DOI: https://doi.org/10.47405/mjssh.v6i9.1026

\begin{tabular}{|c|c|}
\hline 4.581 & Malaysian Journal of Social Sciences and Humanities (MJSSH) \\
\hline $\begin{array}{l}\text { Malaysian Journal of } \\
\text { Social cciences and }\end{array}$ & Volume 6, Issue 9, September 2021 \\
\hline (MJ-SSH) & e-ISSN : 2504-8562 \\
\hline & $\begin{array}{l}\text { Journal home page: } \\
\text { www.msocialsciences.com }\end{array}$ \\
\hline
\end{tabular}

\title{
Strategi Pengurusan Evidens Pentaksiran Bilik Darjah Murid Berkeperluan Khas dalam Program Inklusif Sekolah Rendah
}

\author{
Velerie Wheelervon Primus', Musirin Mosin'1 \\ 1Fakulti Psikologi dan Pendidikan, Universiti Malaysia Sabah (UMS) \\ Correspondence: Velerie Wheelervon Primus (vonnums@gmail.com)
}

\begin{abstract}
Abstrak
$\overline{\text { Kajian ini bertujuan untuk meneroka Strategi Pengurusan Evidens Pentaksiran Bilik Darjah Bagi Murid }}$ Masalah Pembelajaran dalam Program Pendidikan Inklusif di sekolah rendah. Surat siaran KPM bilangan 14, 2018 menyatakan pemansuhan amalan peperiksaan pertengahan dan akhir tahun bagi murid tahap 1, telah dimansuhkan bermula 2018. Peperiksaan yang sebelum ini dijalankan telah digantikan dengan sistem pentaksiran yang lebih objektif (LPM, 2018). Murid masalah pembelajaran dalam program inklusif juga tidak terkecuali daripada sistem pentaksiran yang baharu ini. Namun demikian, pelaksanaan program inklusif ini menimbulkan masalah guru di kelas perdana untuk menjalankan pentaksiran antara murid perdana dengan murid berkeperluan khas. Oleh itu, kajian ini bertujuan untuk meneroka strategi pengurusan perancangan PBD Murid Berkeperluan Khas (MBK) dalam Program Pendidikan Inklusif (PPI) sekolah rendah. Reka bentuk kajian ini adalah menggunakan kaedah kajian kes yang menggunakan kaedah kualitatif. Empat orang guru iaitu guru akademik, guru panitia, guru penyelaras PBD dan guru besar yang terlibat dalam mengurus dan mengendalikan PBD dipilih secara purposive sampling sebagai peserta kajian. Dapatan kajian menunjukkan bahawa setiap peserta kajian menunjukkan strategi pengurusan PBD mengikut bidang tugas masing-masing. Kajian ini juga membentuk satu kitaran pengurusan yang sistematik untuk memastikan pengurusan PBD murid inklusif di laksanakan mengikut buku garis panduan PBD edisi 2018. Kajian ini adalah signifikan dengan keperluan semasa pendidikan negara yang sedang melalui fasa transformasi kurikulum dan pentaksiran. Pengurusan PBD oleh organisasi sekolah selaku pelaksana utama dasar amat penting dalam menjamin kualiti PBD dalam kalangan MBK PPI. Keberhasilan dan kemenjadian MBK PPI dalam pengurusan PBD yang terancang serta pengajaran dan pembelajaran dapat dikesan dapat memberi peluang kepada MBK PPI untuk mendapat kesamarataan dalam pembelajaran. Dapatan kajian ini juga telah memberi garis panduan kepada guru dan organisasi sekolah untuk mengurus dan merancang PBD MBK PPI di sekolah rendah.
\end{abstract}

Kata kunci: strategi pengurusan, evidens pentaksiran, murid berkeprluan khas, program pendidikan inklusif, pentaksiran bilik darjah

\section{Classroom Assessment Evidence Management Strategies for Students with Learning Disabilities in Inclusive Education Programs in Primary Schools}

\author{
Abstract
}


This study is to explore the Classroom Assessment Evidence Management Strategies for Students with Learning Disabilities in Inclusive Education Programs in primary schools. MOE release letter number 14, 2018 has issued the abolition of the practice of mid-year and end-of-year examination for Level 1 students from 2018. Examinations previously conducted have been replaced with more objective assessment systems (LPM, 2018). Pupils with learning difficulties in inclusive programs are also no exception to this assessment system. However, the implementation of this inclusive program raises problems for teachers in the primary class. Therefore, this study aims to explore the management strategies of PBD Students with Special Needs (MBK) in the Inclusive Education Program (PPI) of primary schools. The design of this study is to use a case study method that uses qualitative methods. Four teachers consisted of academic teacher, committee teacher, PBD coordinating teacher and principal who were involved in managing and operating PBD were selected by purposive sampling as study participants. The findings of the study showed that each study participant demonstrated management strategies according to their respective fields. This study also forms a systematic management cycle to ensure that PBD management of inclusive students are implemented in accordance with the 2018 edition of the PBD guideline book. This study is significant with the educational needs of the country, which is undergoing a phase of curriculum and assessment transformation. The management of PBD by the school organization as the main implementer is paramount in ensuring PBD among MBK PPI. The success and development of MBK PPI in the planned management of PBD as well as teaching and learning can be traced are providing an opportunity for MBK PPI to obtain equality in learning. The findings of this study have also provided guidelines for teachers and school organizations to manage and plan for PBD MBK PPI in primary schools.

Keywords: assessment evidence management, students with special needs, inclusive education program, classroom assessment

\section{Pengenalan}

Kurikulum Standard Sekolah Rendah (KSSR) Semakan 2017 diperkenalkan pada tahun 2016 secara berperingkat di sekolah rendah bagi menggantikan Kurikulum Bersepadu Sekolah Rendah (KBSR). Mulai tahun 2017, KSSR telah melalui fasa penambahbaikan apabila Kementerian Pendidikan memperkenalkan KSSR Semakan secara berperingkat mulai tahun 1 sekolah rendah. KSSR Semakan ini dilaksanakan bertujuan mengimbangi set ilmu pengetahuan dan kemahiran seperti pemikiran kritis, kreatif dan inovatif, penyelesaian masalah dan kepimpinan untuk membolehkan murid bersaing pada peringkat global (Mahdzir Khalid, 2017). KSSR bertujuan melahirkan insan yang seimbang, berfikiran kreatif, kritis dan inovatif melalui tunjang-tunjang komunikasi, sains dan teknologi, perkembangan fizikal dan estetika, keterampilan diri, kemanusiaan dan kerohanian, sikap dan nilai (KPM 2018).

Dokumen semakan terbaharu ini digubal dalam bentuk pernyataan standard yang menjelaskan komponen dan elemen yang diajar oleh guru. Pernyataan standard terdiri daripada Standard Kandungan (SK) dan Standard Pembelajaran (SP) yang perlu dikuasai oleh murid dalam suatu tempoh dan tahap persekolahan yang terkandung dalam Dokumen Standard Kurikulum dan Pentaksiran (DSKP). Melalui Pentaksiran Bilik Darjah, seseorang murid itu tidak hanya dinilai berdasarkan peperiksaan sematamata. Malah pentaksiran murid juga dibuat berdasarkan kepada evidens pentaksiran yang dikumpulkan oleh guru berdasarkan pemerhatian dan penilaian berterusan sepanjang proses $\mathrm{P} \& \mathrm{P}$ di dalam bilik darjah (Wan Huzairi, 2017). Strategi pengurusan evidens pentaksiran ini dilakukan berpandukan kepada Buku Panduan Pelaksanaan PBD edisi 2019.

Walaupun PBD ini sebenarnya dirangka berdasarkan konsep pentaksiran formatif yang sudah lama diperkenalkan namun setiap perubahan akan sentiasa membawa kebimbangan kepada guru yang memainkan peranan sebagai agen pelaksana kurikulum (Keddie, 2018). Perubahan ini dilakukan agak drastik jika dibandingkan dengan perubahan-perubahan yang telah dilakukan sebelum ini. Secara rasminya maklumat telah disampaikan oleh pihak KPM bermula Oktober 2018 dan mula dilaksanakan diperingkatkan sekolah bermula Januari 2019. Dalam tempoh empat bulan ini rangka kerja PBD telah 
diberikan kepada pihak pentadbir sekolah dan maklumat ini perlu disampaikan kepada para guru dan waris yang terlibat secara langsung. Setiap perubahan yang dilakukan dalam pendidikan memerlukan tempoh masa sekurang-kurangnya satu tahun untuk memastikan sistem itu diperkenalkan sepenuhnya kepada semua individu yang terlibat secara langsung dengan pelaksanaan sistem tersebut. Latihan dan kursus yang bersesuaian juga perlu diberikan kepada guru-guru untuk memastikan kompetensi mereka untuk melaksanakan perubahan yang telah diperkenalkan (Kwiek \& Szadkowski, 2018).

Perubahan dapat dilakukan dalam tempoh masa yang terdekat sekiranya pihak penggubal dasar mempunyai kepercayaan bahawa guru-guru mampu untuk melaksanakan perubahan yang bakal diperkenalkan (Donina, Seeber \& Paleri, 2017). Kenyataan ini didapati agak menarik untuk dipertimbangkan memandangkan pengenalan PBD untuk murid-murid tahun satu hingga tiga dilakukan dalam tempoh masa terdekat, iaitu hanya dalam empat bulan sahaja. Walaupun, perancangan untuk memperkenalkan PBD telah dilakukan untuk tempoh masa yang agak panjang, namun pengenalan pada peringkat sekolahtelah dilakukan dalam tempoh yang amat singkat. Ini menimbulkan persoalan kepada penyelidik sama ada guru-guru ini sudah mempunyai kompetensi untuk melaksanakan PBD atau kompetensi ini akan dibangunkan ketika mereka mula melaksanakan PBD. Guru-guru yang mempunyai kompetensi untuk melaksanakan sesuatu program yang baharu diperkenalkan selalunya sudah mempunyai pengalaman dan pengetahuan tentang program yang diperkenalkan (Keddie, 2018). Ini juga menimbulkan persoalan tentang pengalaman dan pengetahuan yang dimiliki oleh guru-guru ini untuk melaksanakan PBD.

PBD telah diperkenalkan dalam sistem pendidikan kebangsaan dalam tempoh yang amat singkat tanpa diberi kursus dan latihan kepada guru. Kalai Selvan (2020). Oleh itu, keadaan ini telah memberi ruang kepada penyelidik untuk melakukan penyelidikan ini memandangkan Kwiek dan Szadkowski (2018) mengatakan guru-guru memerlukan ruang masa yang agak panjang untuk mempelajari serta menzahiri perubahan yang telah dilakukan. Pendapat ini bercanggah dengan apa yang dikatakan oleh Keddie (2018) yang berpendapat perubahan dapat dilakukan pada bila-bila masa sekiranya pihak penggubal dasar beranggapan guru-guru mempunyai kompetensi untuk melaksanakan perubahan yang bakal diperkenalkan. Oleh kerana PBD merupakan satu ilham baharu yang diperkenalkan di peringkat sekolah maka ini menampakkan satu keperluan untuk menyelidik perkara ini secara mendalam. Tambahan pula, sehingga kini belum ada lagi penyelidikan yang dilakukan untuk menyelidik cara guru-guru sekolah rendah melaksanakan PBD yang merangkumi tiga aspek iaitu kurikulum, pengajaran dan pentaksiran.

Buku Panduan pentaksiran PBD KPM edisi pertama pada 2018 dan edisi kedua pada 2019 juga menyatakan panduan pelaksanaan pentaksiran bilik darjah. Namun dalam buku panduan ini juga tidak menyatakan secara jelas pelaksanaan dan pentaksiran bagi murid berkeperluan khas. Hal ini menyebabkan murid berkeperluan khas selalu tercicir dalam pelaksanaan PBD.

Kementerian Pendidikan Malaysia (KPM) mengamalkan prinsip pendemokrasian pendidikan dan pendidikan untuk semua (Education for All) dalam merancang pendidikan untuk semua golongan kanak-kanak. Semua kanak-kanak tanpa mengira kaum, latar belakang, status ekonomi dan kecacatan mempunyai hak untuk mendapat akses kepada pendidikan termasuk kanak-kanak kurang upaya. Mereka mempunyai hak yang sama rata untuk belajar dan bersosialisasi dalam persekitaran pembelajaran tanpa halangan (barrier-free learning environment). Pendidikan khas ertinya pendidikan bagi murid-murid berkeperluan pendidikan khas di Sekolah Pendidikan Khas (SPK), Program Pendidikan Khas Integrasi (PPKI) dan Program Pendidikan Inklusif (PPI) di sekolah kerajaan atau sekolah bantuan kerajaan pada peringkat prasekolah, rendah, menengah, dan lepas menengah. Pendidikan pada peringkat antarabangsa meletakkan konsep pendidikan inklusif sebagai asas dalam melaksanakan "Pendidikan untuk Semua". Aspirasi pendidikan inklusif juga telah dikongsi oleh pakar pendidikan dan profesional yang terlibat dalam menyediakan perkhidmatan pendidikan khas seperti yang digariskan dalam deklarasi antarabangsa seperti Salamanca Statement (1994), Dakar World Education Forum (2000) dan Convention on the Rights of Persons with Disabilities (UN, 2006).

Pelaksanaan PPI memenuhi hasrat KPM untuk melahirkan murid yang cemerlang menerusi pendidikan yang tidak mendiskriminasikan murid atas kekurangan mereka. Setiap murid termasuk murid 
berkeperluan khas (MBK) adalah istimewa, mempunyai kepelbagaian kebolehan, dan mempunyai hak yang sama rata bagi mendapatkan akses pendidikan yang berkualiti pada semua peringkat persekolahan. Terdapat keperluan untuk menggalakkan penyertaan MBK dalam pendidikan inklusif supaya mereka dapat meningkatkan potensi diri secara optimum. Hal ini perlu disedari dan diambil perhatian oleh semua ahli masyarakat.

\section{Sorotan Literatur}

Guru-guru yang efektif mengaplikasikan ilmu untuk membangunkan proses rancangan PdP terhadap murid-murid bermula daripada perancangan, pelaksanaan dan seterusnya pentaksiran. Pengajaran bermula daripada pemahaman guru tentang apa yang perlu diajar dan bagaimana pengajaran itu diajar. Oleh itu, aktiviti sebelum, semasa dan selepas PdP adalah penting untuk melihat mutu pengajaran guru. Perkara ini sedikit sebanyak membantu guru mencapai objektif pengajaran dan dapat melakukan refleksi selepas pembelajaran terhadap kanak-kanak berlaku.

Kebanyakan guru selesa menggunakan pendekatan kaedah tradisional yang mana guru mengajar dan kemudiannya memberikan latihan, lembaran kerja atau buku kepada kanak-kanak. Oleh kerana ingin mengejar masa untuk menghabiskan silibus (Zamri 2012), guru lebih fokus kepada ujian atau peperiksaan dan mengukur tahap prestasi kanak-kanak berdasarkan pendekatan tersebut. Oleh itu, aktiviti kertas dan pensil menjadi dominan, justeru, guru kurang menekankan konsep pranumerasi yang mementingkan PdP berasaskan konkrit dan sensori.

Kekurangan masa, kerana penumpuan terhadap lembaran kerja, merupakan kekangan dalam pelaksanaan aktiviti yang melibatkan eksplorasi, eksperimen dan projek. PdP perlu menitikberatkan perkembangan holistik kerana domain-domain perkembangan berlaku secara serentak dan berterusan. PdP yang berorientasikan akademik hanya menumpukan sebahagian kecil daripada keseluruhan domain kognitif dan mengehadkan perkembangan domain-domain lain seperti motor halus dan kasar, dan sosial dan komunikasi. Kemahiran akademik sesuai digabungjalinkan ke dalam kurikulum tetapi bukannya dijadikan fokus utama dalam kurikulum untuk awal kanak-kanak. (Noorshafinaz, 2018).

Strategi pengurusan evidens pentaksiran sekolah meliputi proses mengenal pasti evidens, merangsang evidens dan mengutip evidens yang dikesan. Tiga proses ini berlaku serentak dan bergerak secara bersepadu semasa pengajaran dan pembelajaran berlangsung sebagaimana yang ditunjukkan dalam rajah 1.

Rajah 1: Strategi Pengurusan Evidens Pentaksiran Sekolah

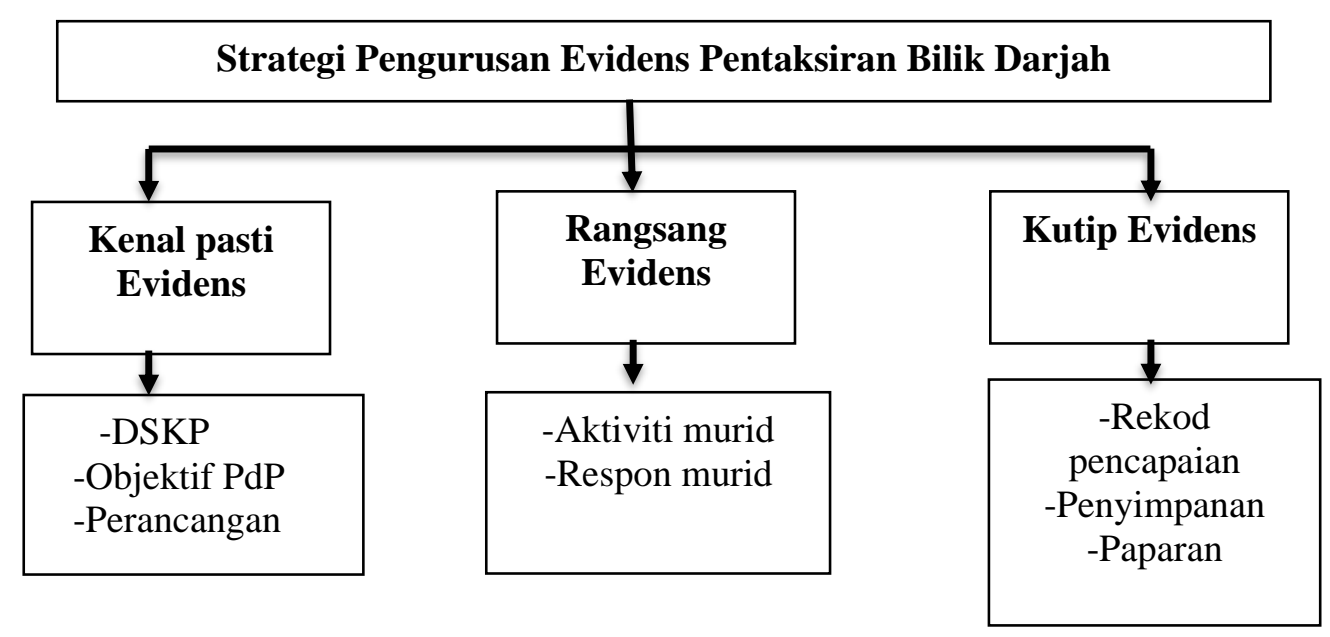

Sumber: Adaptasi daripada Kajian Wan Mohd Huzairi (2017) 


\section{Permasalahan Kajian}

Surat Pekeliling Bilangan 14 menyatakan bahawa pemansuhan peperiksaan pertengahan dan akhir tahun bagi murid tahap satu di sekolah rendah. Peperiksaan yang sebelum ini digunakan untuk menilai murid telah digantikan kepada sistem pentaksiran yang bersifat objektif (KPM, 2018). Murid berkeperluan khas dan murid perdana mempunyai pentaksiran dan pelaporan yang tersendiri. Namun demikian, melalui program inklusif, MBK yang ditempatkan di kelas perdana menggunakan pentaksiran menggunakan standard kandungan, standard pembelajaran dan standard prestasi murid aliran perdana. Kajian Velerie (2020) Menunjukkan bahawa murid MBK di Pedalaman Sabah menunjukkan tahap penguasaan yang minimum. SF Salleh (2018) menyatakan bahawa isu yang sering kali ditemui dalam program pendidikan inklusif ini ialah permasalahan guru mata pelajaran arus perdana dalam pelaksanaan strategi pengajaran di dalam kelas-kelas PPI untuk MBK. Masalah ini juga timbul apabila guru resos yang sepatutnya mengendalikan MBK ini tidak ditempatkan untuk mengajar MBK dalam PPI.

Menurut Wan Huzairi (2017) pengurusan evidens pentaksiran bilik darjah dapat membantu meningkatkan pencapaian murid dalam pelaksanaan pentaksiran di sekolah. Oleh itu, kajian ini melihat enam tema pengurusan evidens pentaksiran bilik darjah dan menggunakan teori pembelajaran untuk membantu pengurusan evidens pentaksiran bagi MBK dalam pelaksanaan PPI murid tahap 1 sekolah rendah.

Surat siaran KPM Bilangan 14, Pemansuhan peperiksaan pertengahan dan akhir tahun (KPM, 2018). Murid berkeperluan khas juga terlibat dengan surat siaran KPM ini. Peperiksaan yang digunakan sebelum ini telah digantikan dengan sistem pentaksiran yang lebih objektif. Namun dalam menjalankan pentaksiran ini timbul beberapa masalah apabila tahap penguasaan murid berada di tahap minimum iaitu tahap penguasaan satu dan tahap penguasaan dua. Rumusan tahap penguasaan yang telah dibuat pada tahun 2019 oleh pejabat Pendidikan Daerah Keningau masih terdapat murid yang mencapai tahap minimum dalam pentaksiran bilik darjah. Melalui PBD KPM (2018) ingin melihat murid tidak lagi menghafal dan kaedah pembelajaran dipelbagaikan. Namun, kehadiran murid berkeperluan khas berserta murid aliran perdana membebankan guru apabila masa yang tidak diperuntukkan dalam setiap subjek adalah terhad. Guru aliran perdana terdedah dengan kursus KSSR dan pentaksiran aliran perdana. Oleh yang demikian, kekurangan pengalaman dan bahan bagi mengurus MBK di dalam bilik darjah. Oleh itu, murid MBK selalu tercicir dan di akhir semester pembelajaran tahap penguasaan mereka masih berada di tahap minimum.

\section{Objektif Kajian}

Objektif kajian ini adalah untuk meneroka amalan pengurusan evidens PBD yang digunakan oleh organisasi sekolah bagi mengurus PBD murid masalah berkeperluan khas dalam program inklusif sekolah rendah. Manakala secara khususnya objektif kajian ini adalah: Meneroka Pengurusan strategi evidens pentaksiran bilik darjah dalam proses menjalankan pentaksiran bagi murid masalah pembelajaran sekolah rendah.

\section{Kerangka Konseptual Kajian}

Kerangka konseptual kajian ini menjadi panduan untuk penyelidik membuat pemerhatian, temu bual dan mendapatkan bukti dokumen sokongan di lapangan kajian. Hala tuju kajian ini adalah untuk meneroka secara naturalistic pengurusan pentaksiran bilik darjah dilaksanakan bagi MBK PPI dan bagaimana pengurusan pentadbiran sekolah iaitu terdiri daripada Ketua Panitia, Penyelaras PBD dan Guru Besar itu sendiri dalam membantu pengurusan PBD MBK PPI. Fokus utama penelitian ini juga adalah tertumpu kepada apa yang berlaku dan bagaimana guru, Ketua Panitia, Penyelaras PBD dan Guru Besar menguruskan evidens pentaksiran dalam konteks MBK PPI di sekolah rendah. Aspek pengurusan evidens ini mengambil kira proses pengurusan yang dilalui oleh seorang guru, ketua panitia, guru penyelaras PBD dan guru besar dalam mengurus dan melaksanakan PBD bagi MBK PPI. 
Skop pentaksiran sekolah pula mengambil kira carta alir pelaksanaan Pentaksiran Bilik Darjah (PBD) yang disediakan oleh Kementerian Pendidikan Malaysia (LPM, 2018).

Rajah 2: Kerangka Konseptual Kajian Pengurusan Evidens Pentaksiran Bilik Darjah

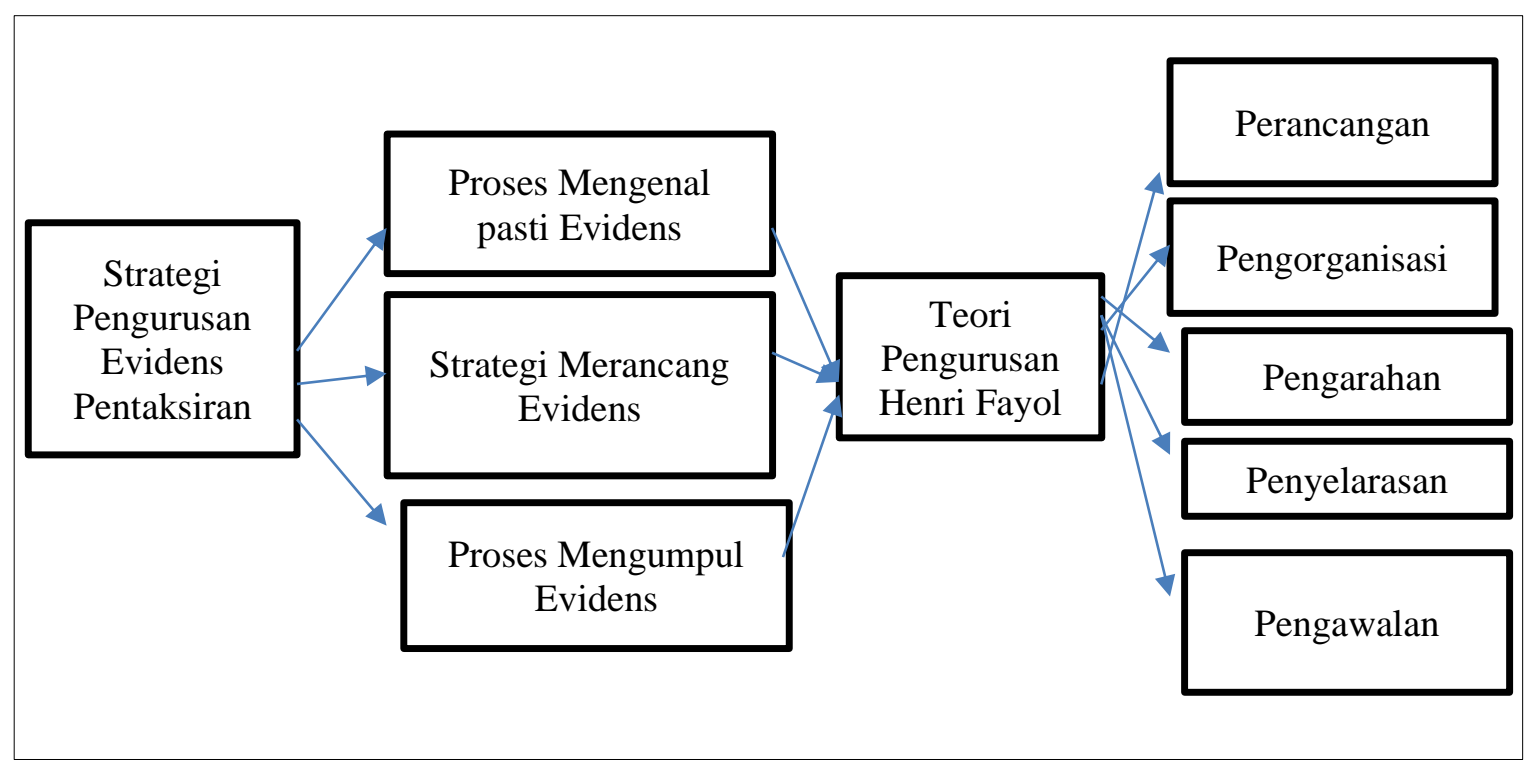

\section{Metod Kajian}

\section{Reka Bentuk Kajian}

Reka bentuk kajian kes secara kualitatif telah dipilih untuk menjalankan kajian ini. Pemilihan kajian kes secara kualitatif ini adalah sesuai berdasarkan kerangka konseptual kajian yang bertujuan untuk meneroka proses yang berlaku secara naturalistik melibatkan peserta kajian di lokasi sebenar yang bersifat grounded theory (Marohaini, 2001; Merriam, 1990, 2001, 2009).

Menurut Donmofer (1990), dua kelebihan utama yang ada pada kajian kes secara kualitatif adalah dapat memberi peluang kepada penyelidik untuk mengakses sendiri lapangan kajian sebenar dan memperolehi dapatan kajian daripada kaca mata peserta kajian sendiri iaitu perspektif emic. Dalam hal ini, penyelidik akan bertindak sebagai instrumen kajian yang hadir sendiri di lapangan kajian sebenar.

\section{Instrumen Kajian}

\section{Pemerhatian}

Dalam kajian ini, kaedah pemerhatian merupakan satu daripada kaedah yang akan digunakan dalam pengumpulan data. Data daripada pemerhatian ini membantu penyelidik untuk meneliti bukti dokumen dan seterusnya membantu sesi temu bual secara lebih mendalam. Kaedah pemerhatian berfungsi sebagai satu alat penyelidikan apabila ia dapat berperanan sebagai hala tuju penyelidikan yang terancang, spontan, boleh direkodkan secara tersusun (Kidder, 1981; Marohaini, 2001). Dalam kajian ini penyelidik telah menjalankan pemerhatian sebanyak 8 kali untuk setiap peserta kajian. Fokus utama dalam pemerhatian ini adalah pengurusan yang dijalankan oleh peserta kajian dalam mengurus pentaksiran murid khususnya MBK yang berada di kelas inklusif.

\section{Temu Bual}

Dalam kajian bersifat kualitatif ini, kaedah pengutipan data deskriptif melalui temu bual adalah cara yang paling lazim terutamanya dalam kajian yang melibatkan pemerhatian sampel kajian (Bogdan \& 
Biklen, 1992, 1998, 2003). Dalam kajian ini, kaedah temu bual digunakan bersama-sama dengan pemerhatian bagaimana keempat-empat peserta kajian mengurus evidens pentaksiran sekolah di dalam proses pengajaran dan pembelajaran serta pengurusan dokumen di peringkat organisasi pentadbiran sekolah. Penggunaan kaedah ini dianggap sama pentingnya dengan kaedah pemerhatian. Tanpa kaedah temu bual, data yang diperoleh daripada pemerhatian tidak akan dapat memberi gambaran yang lengkap tentang apa yang diperhatikan. Melalui temu bual juga, data yang diperoleh daripada pemerhatian dapat diperkukuh dan diperlengkap lagi. Sesi temu bual yang dijalankan bersama-sama dengan peserta kajian seperti ini juga akan menjelaskan maklumat tentang proses perancangan guru, tahap-tahap soalan yang dikemukakan oleh guru, aktiviti rangsangan pembelajaran dan kemahiran yang dilatih oleh guru semasa proses pengajaran dan pembelajaran melalui pentaksiran sekolah yang bersifat 'assessment for learning'. Terdapat dua jenis temu bual yang digunakan dalam kajian ini, iaitu temu bual tidak formal dan temu bual separa formal (Merriam, 1990). Temu bual tidak formal digunakan untuk mengemukakan soalan-soalan secara spontan dalam aliran interaksi, manakala temu bual tidak formal pula menghuraikan cadangan soalan atau isu untuk diteroka semasa temu bual dijalankan (Patton, 1990; Merriam, 1990, 2009) sebagai panduan untuk penyelidik.

\section{Bukti Dokumen}

Pengumpulan data melalui kaedah ini melibatkan beberapa jenis dokumen khususnya dokumen bentuk bertulis seperti buku rekod mengajar guru, buku teks, kertas edaran, rekod pencapaian murid, senarai semak aktiviti dan sebagainya. Jenis dokumen pertama yang digunakan adalah dokumen berbentuk rekod awam (Bogdan \& Biklen, 1992, 1998, 2003) yang lebih merupakan dokumen rasmi sekolah. Dokumen ini digunakan bagi mendapatkan maklumat tentang latar belakang sekolah, statistik jumlah bilangan guru dan murid secara umum.

Bahan bukti dokumen ini berkaitan dengan skop pemerhatian dan pengajaran guru sama ada secara langsung atau tidak langsung. Ia menjelaskan, melengkapkan dan membantu penyelidik untuk membuat triangulasi dapatan kajian secara keseluruhannya. Jika data pemerhatian memerlukan penjelasan lanjut secara lisan melalui temu bual; penyelidik juga turut menjadikan bahan bukti dokumen sebagai panduan soal jawab semasa sesi temu bual bersama peserta kajian. Ini menjadikan temu bual sebagai medium penjelasan lanjut yang dimanfaatkan oleh penyelidik semasa proses pengutipan data sepanjang kajian ini berjalan.

\section{Sampel Kajian}

Sampel kajian adalah individu yang dipilih daripada tempat kajian yang mungkin terdiri daripada guru, murid, pentadbir, kakitangan sokongan dan sebagainya. Dalam konteks kajian ini, peserta kajian adalah merupakan seorang guru yang mengajar PPI, guru panitia, guru penyelaras PBD dan guru besar, sekolah rendah. Pemilihan peserta kajian ini diambil kira pengalaman serta kepakaran peserta kajian dalam mengurus PBD bagi MBK PPI serta ianya mencakupi aspek kepakaran di dalam bidang yang dikaji (expert), mempunyai kebolehan bercakap untuk menghuraikan pendapat dari perspektif emic (expertise) dan juga bersedia untuk membantu penyelidik mendapatkan data untuk kajian (willingness) (Merriam, 1990). Justeru, maka sebelum pemilihan dibuat, penyelidik telah memastikan kriteria pemilihan peserta kajian menepati kehendak untuk membantu menyediakan jawapan kepada soalan kajian ini.

\section{Dapatan Kajian}

Berikut merupakan dapatan daripada kajian ini. Dapatan daripada guru yang menyelaras dan mengendalikan murid inklusif dalam bilik darjah dapat dijelaskan melalui gambar rajah 3. Terdapat empat subtema yang muncul daripada strategi pengurusan evidens PBD ini. Ianya terdiri daripada mengenal pasti evidens merangsang evidens, mengutip evidens dan mentafsir evidens.

Manakala bagi pengurusan strategi bagi ketua panitia pula adalah seperti yang terdapat dalam gambar rajah 4 di bawah. Terdapat 7 sub tema yang muncul daripada dapatan kajian oleh guru akademik ini. 
DOI: https://doi.org/10.47405/mjssh.v6i9.1026

Antara sub tema yang muncul adalah lesson study, PLC, penjaminan kualiti, jadual semakan kerja murid, menyediakan ABM, menyediakan senarai buku teks dan buku kerja murid dan merancang instrument pentaksiran.

Rajah 3: Pengurusan Strategi dan Kaedah Pentaksiran Bilik Darjah

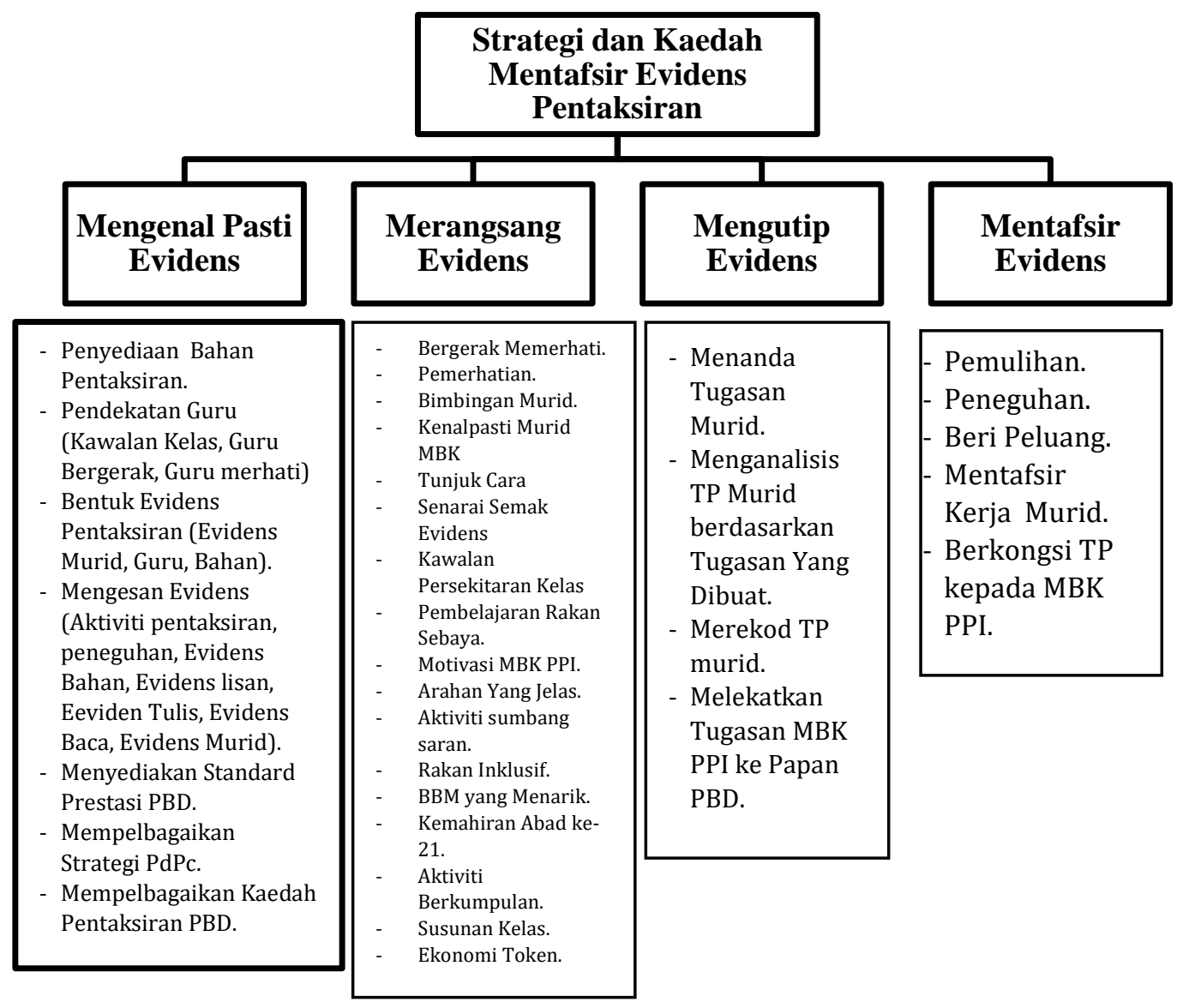

Rajah 4: Pengurusan Strategi dan Kaedah Pentaksiran Bilik Darjah

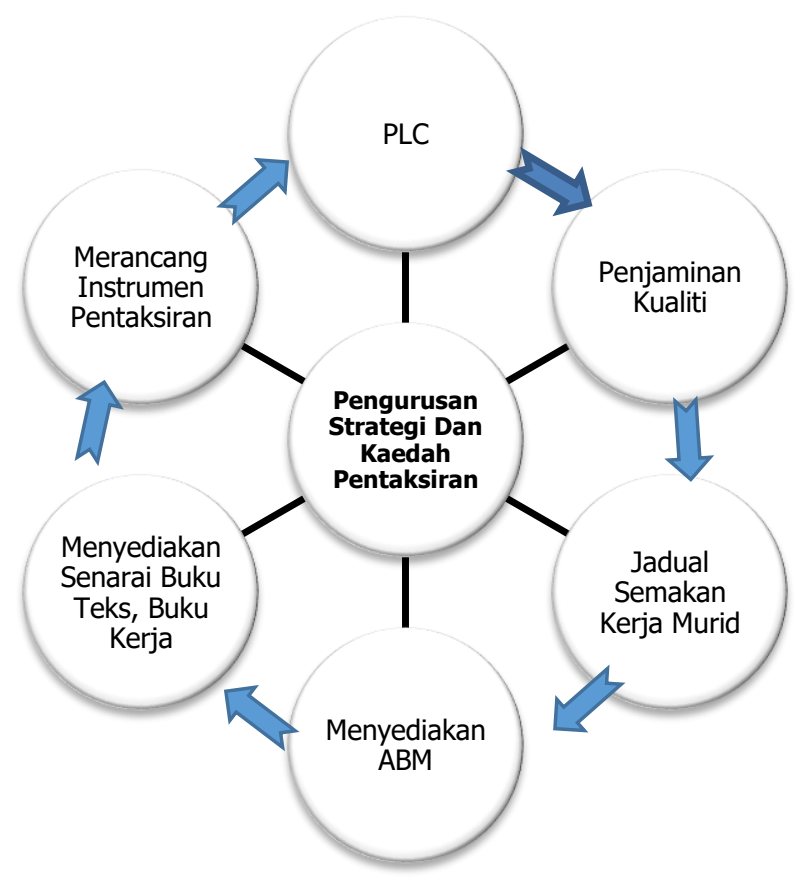




\section{Rajah 5: Pengurusan Strategi dan Kaedah Pentaksiran Bilik Darjah}

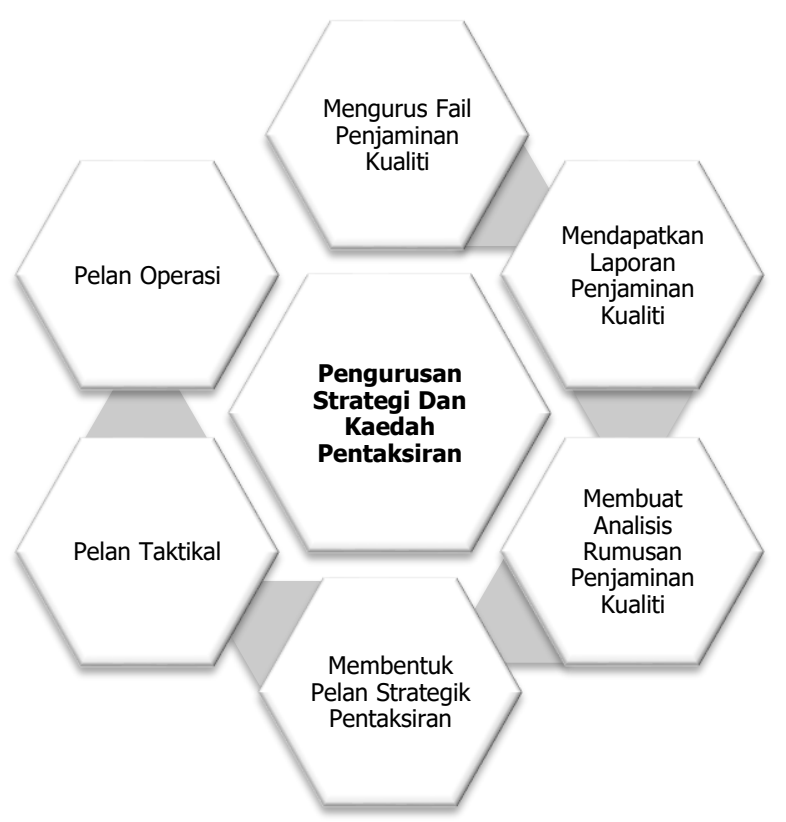

Bagi strategi penyelaras PBD pula, aspek yang diuruskan dalam strategi pengurusan evidens adalah dengan mewujudkan fail penjaminan kualiti. Penjaminan kualiti adalah piawaian untuk menentukan kualiti pelaksanaan PBS mengikut garis panduan yang ditetapkan. Penjaminan kualiti dalam pelaksanaan PBS dilakukan melalui Pementoran, Pemantauan, Penyelarasan dan Pengesanan oleh personel di peringkat Kementerian Pendidikan Malaysia (KPM), Jabatan Pendidikan Negeri (JPN), Pejabat Pendidikan Daerah (PPD) dan sekolah. Penjaminan Kualiti PBS dijalankan secara formal mengikut jadual yang ditetapkan atau secara informal mengikut keperluan KPM / JPN / PPD / Sekolah.

\section{Rajah 6: Pengurusan Strategi dan Kaedah Pentaksiran Bilik Darjah}

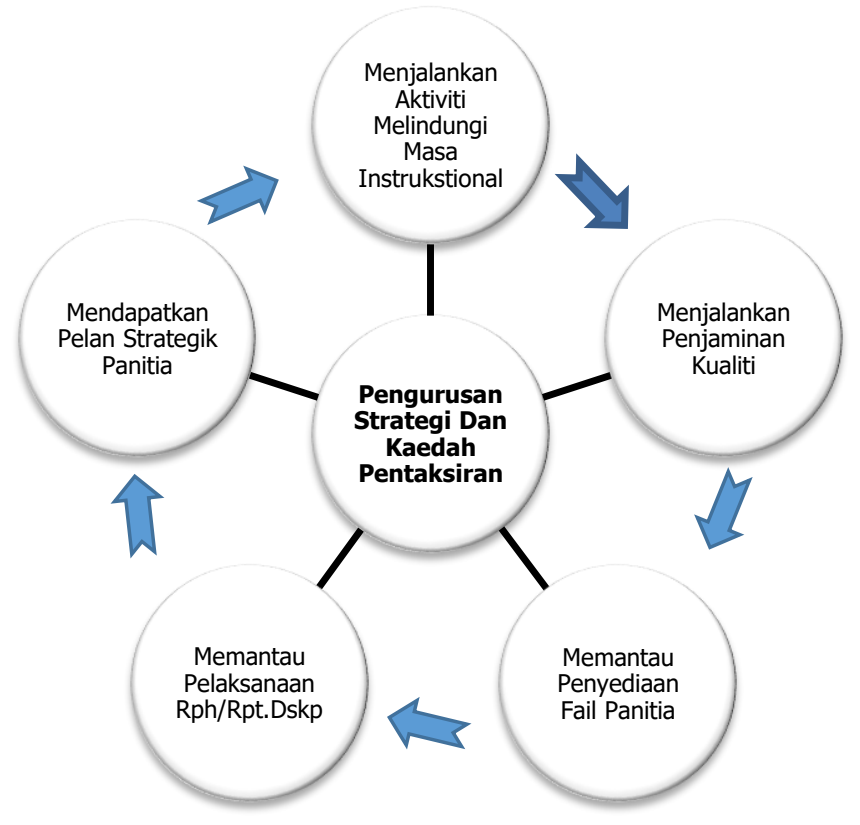

Seterusnya dalam dapatan kajian oleh guru besar pula mendapati terdapat 5 sub tema yang muncul dalam kajian ini. Antara sub tema yang muncul adalah guru besar menjalankan aktiviti melindungi masa instrukstional, menjalankan penjaminan kualiti, memantau penyediaan fail panitia, memantau pelaksanaan RPH, RPT dan DSKP guru dan akhir sekali mendapatkan pelan strategik panitia-panitia. 
DOI: https://doi.org/10.47405/mjssh.v6i9.1026

Dalam tema pengurusan strategi dan kaedah pentaksiran bilik darjah ini terdapat 18 sub tema yang muncul. Penyelidik menggabungkan dapatan kajian dalam persoalan 2 dan persoalan 3 . Hal ini kerana mengikut carta alir PBD yang telah dikeluarkan oleh KPM 2018 menyatakan bahawa strategi dan kaedah ini berlaku secara serentak dalam menjalankan PBD dalam bilik darjah. Selain daripada itu juga persoalan kajian ini digabungkan adalah kerana pengurusan organisasi sekolah hanya menumpukan satu strategi dan kaedah pengurusan yang baik dan dapat membantu pelaksanaan PBD oleh guru yang menjalankannya di dalam kelas.

Rajah 7: Rumusan Pengurusan Strategi Dan Kaedah Pentaksiran Bilik Darjah

\begin{tabular}{|c|c|c|c|}
\hline & \multicolumn{2}{|c|}{$\begin{array}{l}\text { Pengurusan Strategi Dan Kaedah } \\
\text { Pentaksiran Bilik Darjah }\end{array}$} & \\
\hline Guru Besar & Penyelaras PBD & Ketua Panitia & Guru \\
\hline $\begin{array}{l}\text { Menjalankan } \\
\text { Aktiviti } \\
\text { Melindungi Masa } \\
\text { Instrukstional. } \\
\text { Menjalankan } \\
\text { Penjaminan } \\
\text { Kualiti. } \\
\text { Pemantauan } \\
\text { Penyediaan Fail } \\
\text { RPH Guru. } \\
\text { Pemantauan Fail } \\
\text { PBD Panitia. } \\
\text { Mendapatkan } \\
\text { Pelan Strategik } \\
\text { Panitia. } \\
\text { Kajian Tindakan }\end{array}$ & $\begin{array}{l}\text { Mengurus Fail } \\
\text { Penjaminan } \\
\text { Kualiti. } \\
\text { Mendapatkan } \\
\text { Laporan } \\
\text { Penjaminan } \\
\text { Kualiti. } \\
\text { Membuat } \\
\text { Analisis } \\
\text { Rumusan } \\
\text { Penjaminan } \\
\text { Kualiti. } \\
\text { Membentuk } \\
\text { Pelan Strategik } \\
\text { PBD. } \\
\text { Pelan Taktikal. } \\
\text { Pelan Operasi. }\end{array}$ & $\begin{array}{l}\text { PLC } \\
\text { Penjaminan } \\
\text { Kualiti. } \\
\text { Jadual Semakan } \\
\text { Kerja Murid. } \\
\text { Merancang } \\
\text { Penyediaan BBM } \\
\text { Menyediakan } \\
\text { Rujukan Buku } \\
\text { Aktiviti MBK } \\
\text { PPI. } \\
\text { Merancang } \\
\text { Instrumen PBD } \\
\text { MBK PPI. } \\
\text { Kajian Tindakan } \\
\text { Kajian Inovasi }\end{array}$ & $\begin{array}{l}\text { Mengenal pasti } \\
\text { evidens. } \\
\text { Merangsang } \\
\text { Evidens. } \\
\text { Mengumpul } \\
\text { Evidens. } \\
\text { Mentafsir } \\
\text { Evidens }\end{array}$ \\
\hline
\end{tabular}

\section{Kesimpulan}

Dapatan kajian ini diharapkan dapat memberikan implikasi yang positif kepada pihak-pihak tertentu yang menguruskan hal-hal berkaitan dengan dasar pendidikan terutamanya sekali Bahagian Pembangunan Kurikulum, Bahagian Pendidikan Khas, perkembangan kurikulum, pengurusan pentaksiran, latihan pendidikan guru, pentadbiran sekolah, pedagogi, sarana ibu bapa, perkembangan profesionalisme guru, penjaminan kualiti dan pembelajaran murid terutamanya MBK PPI. Kajian ini juga memberi implikasi yang baik kepada organisasi sekolah terutamanya untuk memberi panduan kepada pelaksanaan pengurusan PBD khususnya bagi program Pendidikan Inklusif untuk Murid Berkeperluan Khas (MBK).

Kajian ini dilaksanakan untuk memberi peluang kepada MBK PPI untuk mendapat pembelajaran dan pentaksiran yang sama rata dengan murid aliran perdana. MBK PPI yang menyertai PPI penuh 
perlulah ditaksir bagi mengetahui tahap penguasaan dalam pembelajaran mereka. Garis panduan yang diperolehi daripada kajian ini dapat membantu guru-guru di sekolah rendah untuk melaksanakan pentaksiran kepada MBK PPI secara lebih sistematik.

\section{Rujukan}

Anderson, L. W. \& Block, J. H. (1975). Mastery Learning Models in Dunkin, M. J. (ed), The International Encyclopedia of Teaching and Teacher Education. New York: Pergamon Press.

Ardisal (2019). Pengembangan Pendidikan Inklusif. Journal of Chemical Information and Modeling. DOI 10.1017/CBO9781107415324.004.

Bhasah Abu Bakar. (2003). Asas pengukuran bilik darjah. Tanjong Malim, Perak: Quantum Books.

Bhasah Abu Bakar. (2003). Pendidikan berorientasikan peperiksaan (Exam oriented) dari perspektif pelajar sekolah menengah (Tingkatan 1 hingga tingkatan 3). Kertas kerja dibentangkan di Seminar Pentaksiran Pendidikan Kebangsaan pada 5 - 8 Mei, di Kuala Lumpur.

Buku Panduan Pentaksiran Bilik Darjah Edisi pertama (2018), Kementerian pendidikan Malaysia.

Buku Panduan Pentaksiran Bilik Darjah Edisi pedua (2019), Kementerian pendidikan Malaysia.

Biggs, J. (1998). Assessment and classroom learning: A role for summative assessment? Assessment in Education, 5, 103-110.

Biggs, J. (2003). Aligning Teaching and Assessing to Course Objectives, Teaching and Learning in Higher Education: New Trends and Innovations. University of Aveiro, 13-17 April, 2003

Black, P., \& Wiliam, D. (1998). Assessment and classroom learning. http://litd.Psch.uic.edu/ does/black.p_etal_1998.pdf .

Guskey, T. R. (2001). Mastery learning. Dalam N. J. Smelser \& P. B. Baltes (Eds.), International Encyclopedia of Social and Behavioral Sciences. Oxford, England: Elsevier Science Ltd.

Guskey, T. R. (2005). Formative Classroom Assessment and Benjamin S. Bloom: Theory, Research, and Implications. Paper presented at the Annual Meeting of the American Educational Research Association, Montreal, Canada.

Guskey, T. R. (2007). The Rest of the story: The Power of formative classroom assessment depends on how you use the result. Educational Leadership, Association for Supervision and Curriculum Development, Dis 2007 / Jan 2008.

Guskey, T. R. (2007). Formative Classroom Assessment and Benjamin S. Bloom: Theory, Research and Practice. Dalam McMillan, J. H. (Ed.). Formative Classroom Assessment: Theory into practice. NY: Teachers College, Columbia University.

Hafilah Abd Satar \& Paharudin Arbain. (2015). Amalan pentaksiran berasaskan sekolah (PBS) dalam kalangan guru Bahasa Arab peringkat menengah rendah. Prosiding Persidangan Kebangsaan Bahasa Arab (NCAL2015). 18-19 Ogos 2015, Institut Pendidikan Guru Kampus Pendidikan Islam. Bangi: Selangor.

Kementerian Pelajaran Malaysia. (2011). Surat Siaran Lembaga Peperiksaan Bil. 3 Tahun 2011: Pemakluman Pentaksiran Berasaskan Sekolah (PBS) di Sekolah Rendah dan Menengah Rendah KP.LP.003.07.14.05 (1) bertarikh 29 Julai 2011.

Kementerian Pelajaran Malaysia. (2018). Surat Siaran Lembaga Peperiksaan Bil. 14 Tahun 2018: Pemakluman Pemansuhan peperiksaan pertengahan dan akhir tahun)murid tahap 1 di Sekolah Rendah -KP.LP.003.07.14.05 (1) bertarikh 29 Julai 2011.

Lembaga Peperiksaan Malaysia. (2012). Panduan Pengurusan Pentaksiran Berasaskan Sekolah (PBS), Kementerian Pelajaran Malaysia.

Lembaga Peperiksaan Malaysia. (2003). Pentaksiran Lisan Berasaskan Sekolah (PLBS). Kuala Lumpur: Kementerian Pendidikan Malaysia.

Lembaga Peperiksaan Malaysia. (2003). Prosiding Seminar Pentaksiran Pendidikan Kebangsaan: Pentaksiran Alaf Baru. 5 - 8 Mei 2003. Kuala Lumpur: Kementerian Pendidikan Malaysia.

Low, Hui Min (2018). Pre-service teachers' attitude towards inclusive education for students with Autism Spectrum Disorder in Malaysia. International Journal of Inclusive Education

Mazliana Md Said (2019). Kesahan dan kebolehpercayaan instrumen literasi pentaskiran bilik darjah melalui Model Pengukuran Rasch. Seminar Antarabangsan Isu-isu Pendidikan (ISPEN2018)

Khalid Ab (2016). Pembentukan Sikap Positif Guru Terhadap Pelaksanaan Aktiviti Pentaksiran. Journal of Personalized Learning. 
DOI: https://doi.org/10.47405/mjssh.v6i9.1026

Sebrina (2019). Implementasi kurikulum pada sekolah penyelenggara pendidikan inklusif. Jurnal Penelitian Ilmu Pendidikan. Doi 10.21831/jpipfip.v11i2.19748.

Saloviita, Timo (2016). Teacher attitudes towards inclusive education in Finland and Brandenburg, Germany and the issue of extra work. European Journal of Special Needs Education

Sh. Siti Hauzi (2019). Pengetahuan, Kemahiran, Sikap dan Masalah Guru dalam Melaksanakan Pentaksiran Bilik Darjah Bahasa Melayu di Sekolah Rendah. Jurnal Pendidikan Bahasa Melayu.

Wan Mohd Zuhairi Wan Abdullah. (2017). Pentaksiran dalam proses pengajaran dan pembelajaran Bahasa Arab di sebuah sekolah menengah. Kertas Projek Sarjana Pendidikan yang tidak diterbitkan. Fakulti Pendidikan, Universiti Malaya, Kuala Lumpur 